one instrument for spreading abolitionist doctrines. Such factors do much to explain why peddling did not thrive so greatly in the South as elsewhere in the United States.

To view the peddler simply as a distributor of wooden nutmegs and the source of innumerable stories of Yankee tricks is to ignore his importance. Even the clock peddlers, who seemed to be the most suspect of all, continued to vend their goods in the same localities for twenty or thirty years, a clear indication of the merit of their wares. That peddlers survived against so many hostile forces is evidence both of their hardihood and of their real services in the merchandising world of the South.

Lewis E. Atherton,

University of Missouri.

\title{
A New Book on Business History
}

Next month will appear The House of Hancock by William T. Baxter, professor of accounting at the University of Cape Town. This publication is one of the Harvard Studies in Business History, edited by Professor N. S. B. Gras; prior to public sale, copies are being sent to members of the Business Historical Society.

Professor Baxter's book reaches back farther into history than any other volume in the series, beginning with the business scene in colonial Boston forty years before the day of the mercantile enterprise described in The Jacksons and the Lees, by Kenneth W. Porter, and sixty years before the post-Revolutionary period discussed in The Massachusetts First National Bank of Boston, by Professor Gras. Professor Baxter writes of two generations of merchants in eighteenth-century America, on the world's frontier, supplying a people who clamored for goods from the older countries, who produced little for direct trade in return, and who had achieved no stable currency with which to pay for what they wanted. The contribution of the Hancock family to the development of early New England is generally assessed in terms of John's political activity, without consideration of the business which brought goods into this country, contrived to find goods acceptable abroad as settlement for the imports, sent out ships to link the new country with the old, and helped to perform the functions of banker and clearing house for trade and for government officials. This is the story that The House of Hancock unfolds. 
Thomas Hancock set up shop as a bookseller within a stone's throw of Boston's waterfront in 1724, half a century before the Redcoats, seeking the arrest of his famous nephew and heir, marched to Lexington. Books and stationer's goods were soon crowded into a corner by the sterner necessities of life-cloth, hardware, leather, tea, salt, flour, and other provisions. And in payment, since even local currency was scarce, country traders who looked upon Hancock as their wholesale supplier brought in farm produce, lumber, poultry, or hogs. Professor Baxter has unraveled an interesting system of "bookkeeping barter" whereby debits and credits in goods or services were transferred from one account to another and in which the word "cash" occurred rarely; frequently a third person became party to a deal merely as a means of transmuting what a debtor had into what a creditor wanted through an intermediate swap.

Importation of goods required a return trade, and here again intermediate exchange was of ten necessary. New England's country produce went to feed Newfoundland fishermen in exchange for fish; fish went to the Caribbean and was turned into a cargo for London or Holland, or sometimes went even to Spain, where it fetched a price in sterling. Whale oil and potash went straight to English ports. Hancock therefore sent his own ships whaling and put capital into potash-making. England's wars with Spain and France strengthened the credit position of colonial merchants, Hancock prominent among them, and brought some easement in exclrange.

By such means Thomas Hancock built up a stubstantial fortune and sound reputation. His methods of operation through a series of partnerships to spread his risks, through agents abroad and trustworthy skippers on his ships, who had to make decisions wisely without benefit of advice from the master, are shown in detail by Professor Baxter.

In 1763, Thomas I lancock had made his nephew John a partner in the business, and when Thomas died in 1764 as the richest man in Boston, John became his heir and successor. The mantle fell, however, on indifferent shoulders. John had neither the capacity nor the interest to maintain so diverse an enterprise. The difficulties of trade were growing still more complex as restrictive legislation, taxes, and non-importation pacts harassed the spirits and hampered the profits of colonial merchants. Moreover, a definite downward turn in the trend of prices and a cooling of demand for goods cut into the rewards of business ventures. John Hancock turned to politics, and an agent wound up the declining affairs of the business. The story of the house of Hancock ends with the American Revolution.

William T. Baxter came from Edinburgh as a Commonwealth 


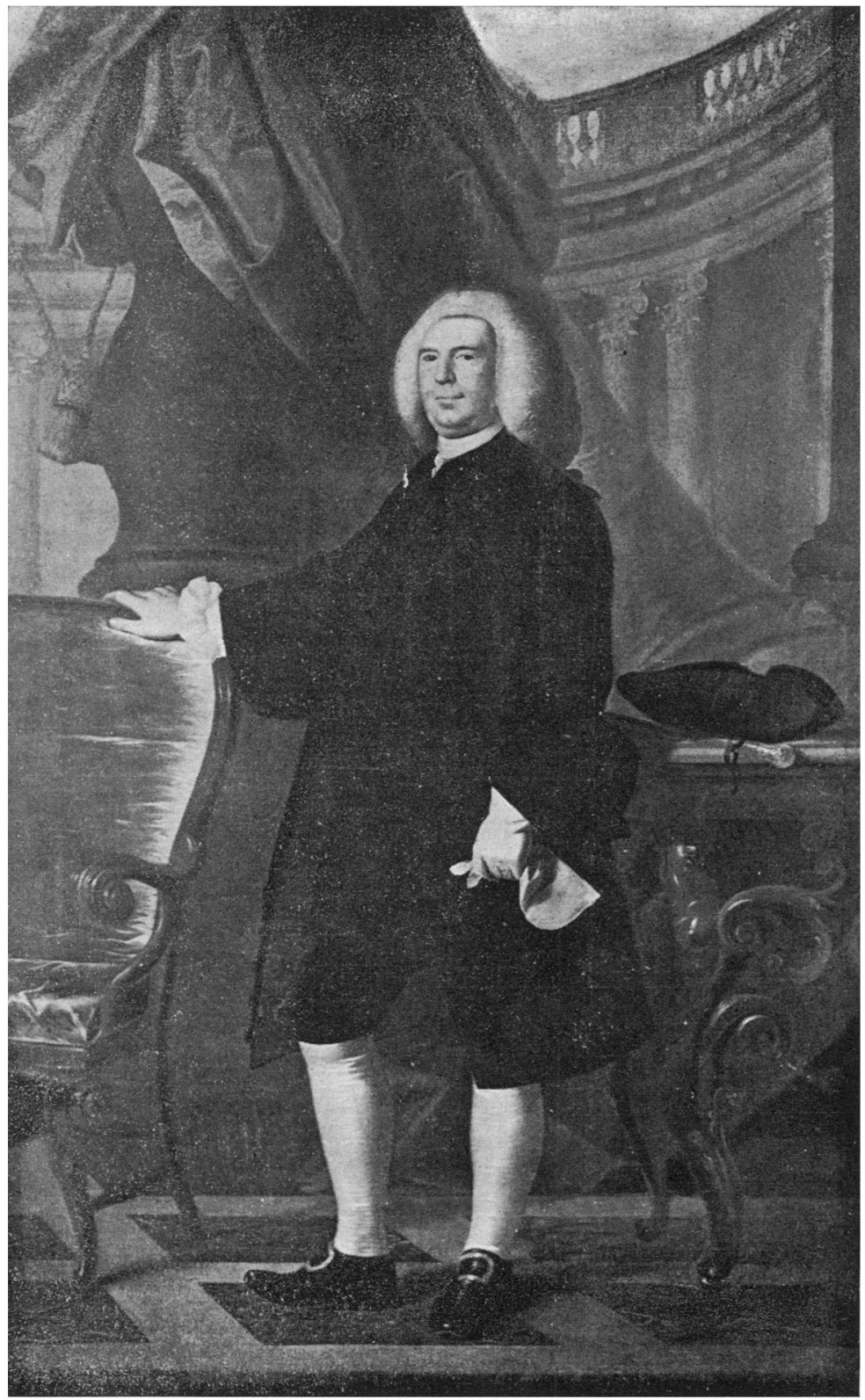

THOMAS HANCOCK

Founder of the House of Hancock 
Fellow and sought out Professor Gras because of an interest in the field of Business History. The Hancock manuscript collection in Baker Library at the Harvard Graduate School of Business Administration was put at his disposal, and from this source chiefly he has built up his story, although other libraries and historical collections also yielded bits of evidence. To an accountant, the record books of such an enterprise as is here described would be a challenge, and doubtless his accountant's flair has helped Professor Baxter to reconstruct ive intricate transactions which for a period of fifty years comprised the rise and fall of the house of Hancock. The books of account upon which he had to rely chiefly were the journals. The Hancock ledgers have been lost in the welter of years, but the survival of certain ledgers kept by Daniel Henchman, Thomas Hancock's father-in-law, has made possible a rounded conception of the accounting procedure used by Hancock, since a marked similarity in the methods of the two men is evident from their journals. The manuscripts also include bills, both rendered and received, and letterbooks covering most of the period. From these letters the author has drawn the details of operation plans, methods, results - the failures and triumphs of a hardpressed business man.

The book is delightfully written, with a deft and easy touch. The author has made himself familiar with the setting; and eighteenth-century Boston, a small town for all its importance in which the arrival of a ship from London could start a flurry of activity, is shown lying between the waterfront and the suburban eminence of Beacon Hill, where the Hancock mansion stood. The picture, however, is limited in scope. We see the Hancock business in isolation, with scanty information about enterprises surrounding it or the merchants who were competing with it. Professor Baxter views the political scene with a less jaded eye, perhaps, than if he were indigenous to Yankee soil. He shows trade restrictions and resulting protests not as the hackneyed issues of a political struggle but as the practical impact of a remote government on essential business. By the device of putting an appendix after many of the chapters, the author, without tying knots in the main thread of his story, has given a wealth of illustrative material and full-flavored samples of correspondence which show the men of the times in their own words. Although in the course of the Hancock trade, certain portions seem repetitious or unnecessary, a succinct concluding chapter pulls these parts into focus.

This volume demonstrates the possibility of reconstructing the history of a business. from records alone. In this case there is no surviving successor firm to throw light on its forebears and no one to recount traditions of the old days. Here the whole story comes 
from written, ofttimes scrawled, words and figures. Professor Baxter has shown that such a task can be done, not merely accurately, but with an imaginative accuracy, and in his hand the kaleidoscope of facts presents a vital picture.

Josepha M. Perri, Harvard University.

\section{A Book Concerning a Country Store}

A short volume has recently been published by the Texas State Historical Association on the history of a country store which is unique in style and content and unusual in its subject. The book is Charles Schreiner, General Merchandise, by J. Evetts Haley. Written largely from the records of the Charles Schreiner Company, of Kerrville, Texas, and the memories of old-timers of the community, the volume tells a story of business which began in the hill country of Texas on December 24, 1869, a story of success which is still continuing.

The second chapter of the book, Customers' Accounts, describes the store, inside and out, and tells of the business it did in terms of the goods sold and other functions performed, as found in store records. The fourth chapter, The Schreiners as Storekeepers, treats of the men and of their policies and management methods. To a subject for which we have far too little specific information, the general country store, the volume makes a real contribution, though a fuller and broader treatment is much to be desired.

Charles Schreiner, General Merchandise, is written in a striking style. It has a quality of verisimilitude which is more characteristic of fiction than of historical writing. The emphasis of the book is, first of all, on men - on character, personality, and motive - and it treats of them in a very individual and subjective way. The atmosphere of reality is enhanced by conversation and by pictures of men and places scattered throughout the volume. Such a style, while effective, must be used with care. There is a danger that it may result in fiction supplied by the imagination of the writer rather than in an effective statement of facts drawn from actual historical records. To be sure, the historian can draw on his own informed imagination, but he must guard against the pitfalls of fictionalized history by disciplining his imagination, by carefully documenting his facts, and by making clear at all times what he is 